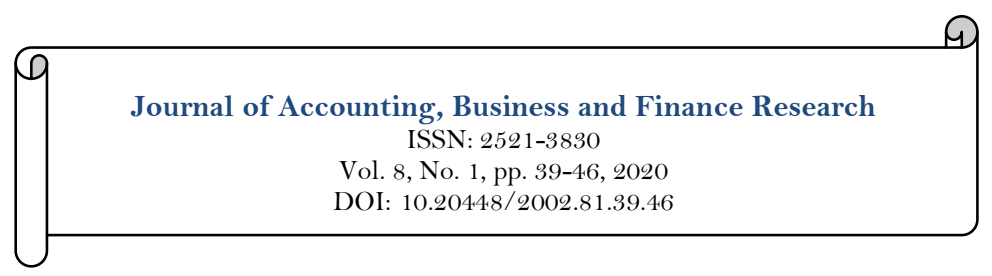
Updates

\title{
Quality Imperative Value Addition and the Performance of Medium Scale Manufacturing Enterprises in Kenya
}

\author{
Evans Mwasiaji \\ Lecturer, School of Business, Kenyatta University, Nairobi, Kenya. \\ Email:mwasiajiet@yahoo.com
}

\begin{abstract}
Kenya's manufacturing sector has stagnated at about USD 5 billion for over ten years in addition to lose of market share and competitiveness at the international level. This study therefore investigated quality imperatives and the performance of medium scale manufacturing enterprises in Kenya. Data was collected from 56 senior management staff from the sampled enterprises in Nairobi City County. Mean responses received in a Likert scale of $1-5$ for each of the tested item was calculated by summing up all the codes and getting the average of the 56 respondents. These results revealed that there is a significant difference in the firms' level of performance on various quality imperatives. To establish the level of performance of MSMEs in relation to the eighteen (18) tested items, a One-Way Analysis of Variance was conducted on the mean response on the items tested. The study established a mean response at 3.31 and a standard deviation at 0.80 . The study concluded that Quality is critical in achieving sustainable competitive advantage. Hence the urgent need for MSMEs to further improve product quality and the production process for purposes of consumer and employee satisfaction and ultimately enhanced competitiveness at the local and international market. The study recommended that key processes within MSMEs should be reengineered to undertake the quality improvement journey, because their traditional management methods seem to be wholly inadequate to attain and sustain high quality in a globalized and competitive business environment.
\end{abstract}

Keywords:

Quality

Competitiveness

Manufacturing

Quality imperatives

Medium scale enterprises

Licensed:

This work is licensed under a

Creative Commons Attribution 4.0

License.

Publisher:

Scientific Publishing Institute

Accepted: 3 January 2020

Published: 13 January 2020

Funding: The study did not have any funding support.

Competing Interests: The author declares that there are no conflicts of interests regarding the publication of this paper.

\section{Background Information}

Globally, a buoyant manufacturing industry that maintains the desired level of excellence in product quality is accepted as a catalyst towards industrialization and improvement in overall welfare of the citizenry (Jara \& Escaith, 2012; Republic of Kenya, 2016). The manufacturing industry and particular firms in the small and medium scale categories have therefore been shown to play a major role in achieving the desired industrial and economic development objectives of national economies (Banjoko, Iwuji, \& Bagshaw, 2012; Daveri \& Lasinio, 2007). While the actual contribution to sustainable economic development for various firm categories in the manufacturing sector differ due to their diverse nature, the Medium Scale Manufacturing Enterprises (MSMEs) for instance have been hailed as critical in employment creation and poverty alleviation (Ayyagari, Beck, \& Demirguc-Kunt, 2007; Tuan \& Yoshi, 2010). The MSMEs also earn foreign exchange in addition to enhancing regional economic balance through industrial dispersal (Callahan, Smith, \& Spencer, 2013). With increased unemployment rate arising from harsh economic conditions, the development of MSMEs and other 
firms in the SME sector is therefore considered a counteracting force by creating productive employment and generating value added income for wealth creation and poverty reduction (Haltiwanger, Jarmin, \& Miranda, 2010). Due to their size, the MSMEs require a relatively small capital investment for operations as compared to large enterprises, thereby offering a relatively high labour to capital ratio (Rice \& Strahan, 2010).

However, a striking trend in the world is the growing Internationalisation of business operations (Liesch, Buckley, Simonin, \& Knight, 2012). With never ending improvements in information technology together with reduction in trade barriers, more industries and countries have continued to expand their presence at the global business arena, through trade in goods and services (Bausch, 2011; Klapper, Amit, \& Guillen, 2008; Leahy \& Montagna, 2008). The volume of local and international commerce in goods and services and foreign investment, has quickly grown to the current complex and hyper competitive global business environment (McKenzie, 2011; Organisation for Economic Co-operation and Development, 2004). New products, markets and changes in consumer tastes and preferences continue to emerge, hence further compounding the needed industrial competitive advantages, including the need to keep pace with newer technologies and the everchanging customer service preferences (McGrath, 2013).

One of the areas that continue to receive a lot of customer attention and has weakened or strengthened the survival possibilities of business enterprises is in the quality of the products supplied to the market (Khrystyna, Mirmulstein, \& Ramalho, 2010; Sinha, Akoorie, Ding, \& Wu, 2011). The increasingly available similar or substitute products have given customers options thus raising their expectations on product quality including reliability, value for money and durability (Corwin \& Puckett, 2009; Mead \& Liedholm, 1998). Quality management is hence no longer optional, but an integral requirement in a firm's armoury in the battle for a competitive position in the market place (Bos-Brouwers, 2010; Mead \& Liedholm, 1998). Although price, brand loyalty, attractive product features, and technical innovations are still very important in the market, the quality of products has surged ahead in relative importance (Jara \& Escaith, 2012). To further complicate the situation, the continuous improvement in information technology and lessening of trade barriers has inevitably increased the level of competition at the local and international market place (Abeh, 2017; McGrath, 2013).

In Kenya, the industrial sector comprises manufacturing, construction activities, quarrying and mining, out of which value addition (manufacturing) accounts for about 65\% (RoK, 2016). The Kenya Government has therefore proposed support to the manufacturing sector so as to raise its GDP share to 15 percent by year 2022 due to its strong forward and backward linkages with other sectors in the economy. Kenya's manufacturing sector serves both the local and export market mainly in the East African region. This sector is subdivided into twelve sub-sectors which are in processing and value addition, with MSME activities are prominent in sub-sectors such as food, beverages, textile, apparel \& footwear, wood \& wood products; pulp, paper \& publishing, non-metallic products, plastic \& rubber, basic metal, iron \& steel (Kenya Association of Manufacturers, 2018). In addition, the MSMEs constitute a dynamic and critical part of the private sector whose entrepreneurial viability is essential in inducing responsiveness to fluctuations in the national economy (Liesch et al., 2012).

However, the performance of the manufacturing enterprises, particularly those in the SME sector, has not grown as expected. According to Republic of Kenya (2019) the manufacturing sector has had very minimal growth stagnating at about USD 5 billion for more than a decade, and continues to lose market share in East African and competitiveness in the international trade. For instance, Kenya held a dominant position supplying the region with manufactured goods with Uganda as the largest trade partner, though lately, Kenya's manufactured exports to Uganda and Tanzania dropped in year 2017 by 5.4 and 29.59 percent respectively as compared to 2013. Many manufacturing companies such as Procter and Gamble and Reckitt Benckiser have in the recent past relocated from Kenya to other regions citing high cost of doing business. As a result, the manufacturing sector's contribution to GDP over the last five years has been on a downward trend, contributing 10.7 percent of GDP in year 2013, though this progressively declined to 8.4 percent as at 2017. In 2019, the situation had still not improved with at least four Kenyan companies announcing plans to sack their employees before end of 2019. Among the companies that issued the dreaded memo to their staff include East African Portland Cement, Telkom Kenya, Stanbic Bank Kenya and Diageo Africa Business Service Centre. East African Portland Cement for instance declared in August 2019 all positions redundant, citing massive losses and persistent financial woes as the reasons behind the painful decision.

Despite the worrying trend in Kenya's manufacturing sector, there is inadequate empirical data on MSMEs because most studies have examined micro, small or large enterprises creating a missing middle. Moreover, very few studies especially in relation to quality management have been conducted for MSMEs that takes into account the unique nature of activities and challenges experienced by these types of firms. It is against this background that the current study sought to examine quality management practices for MSMEs being a reflection of how these kind of firms in Kenya have configured their processes to achieve and maintain the desired level of excellence in product quality in a globalized market place. 


\section{Materials and Methods}

The study adopted descriptive design to obtain data with respect to the identified variables arising from extensive review of relevant literature. The unit of analysis for this study were MSMEs with an employment level of between fifty-one (51) and two hundred persons (200). The chosen MSMEs were from a cross section of the manufacturing or value addition sector. The employment level of between 51 and 200 was arrived at considering the definition of micro and small enterprises provided for in the MSE Act of 2012 (Republic of Kenya, 2012) and also the definition by the European Economic and Social Committee.

Nairobi City County in Kenya was chosen because it is not only the regional business hub, but also because over 80 per cent of the manufacturing or value addition enterprises are based there (KAM, 2018). The manufacturing sector was chosen not only because of its critical role towards Kenya's industrialization, but also because its output is often traded in local, regional and international markets than service output. The manufacturing firms are also more likely to be in direct competition with foreign firms attempting to develop substitute technology using similar processes and targeting the same customers. Moreover, the industrial sector in Kenya comprises of the manufacturing, quarrying and mining and construction activities, out of which the manufacturing activities accounts for the greatest share. In addition, industrialization (which includes manufacturing), has been hailed as the "engine for growth" for newly emerging economies in the world and that is why the Kenya Government recognises this as a core goal to the attainment of vision 2030 (RoK, 2013). The Chief Executive Officers, General Managers or Senior Management Executives of the MSMEs were identified because they would be in a better position to respond to questions touching on the overall competitiveness of their respective enterprises.

A Sampling Frame was prepared as per the list obtained from the Kenya Association of Manufacturers and the licensing department of the Nairobi City County Government. This was done to ensure only the inclusion of legal business enterprises. It was also necessary to use both lists because not all MSMEs are members of KAM. The next step was to augment the list using data from the Kenya National Bureau of Statistics. As a result, 485 enterprises were identified from the various economic activities in the manufacturing sector as follows: Food Processing, Wood Workings, Fabricated Metal Products, Non-metallic products and Leather, Textiles and Garments.

Out of the 485 enterprises, 392 are located or have their offices within Nairobi City County which is the study's geographical setting. Of these 392 firms, only 90 fell within the required employment level of between 51 and 200 persons as per the study's definition of an MSME. The short-listed 90 enterprises were then classified into three (3) clusters based on employment level of 51-100, 101-150; and 151-200. In each of the clusters, the selected firms were further subdivided into five (5) substrata of Food Processing, Wood Workings, Fabricated Metal Products, and Leather, Textiles and Garments. This was done to ensure that the whole population was evenly covered to avoid biased representation (Oslo Manual, 2005). In addition, this method was deemed useful in three ways. First, it was conceived that each stratum would be homogenous internally but heterogeneous with other strata of the population. Secondly, stratification would be useful if there was going to be a need to study the characteristics of certain sub-groups. Lastly, it was useful for the application of different methods of data collection where necessary in the different parts of the population (Saldaña, 2011).

Using Krejcie and Morgan (1970) table of determining sample size, 73 is the actual number of firms that is required to form a representative sample, out of a population of 90. The applicable formula is: $s=X^{2} N P\left(1^{-}\right.$ $P) \div d 2(N-1)+X_{2} P(1-P)$, at a confidence level of $95 \%$ and a margin of error of plus or minus $5 \%$, where:

$s \quad=$ required sample size.

$X_{2}=$ the table value of chi-square for 1 degree of freedom at the desired confidence level (3.841).

$N \quad=$ the population size.

$P \quad=$ the population proportion (assumed to be .50 since this would provide the maximum sample size).

$d \quad=$ the degree of accuracy expressed as a proportion (.05).

Having determined the required sample size to be 73 MSMEs out of 90, it was found prudent to add additional enterprises to cover for possible non responses from the respondents, and also increase the reliability of the findings. The residue MSMEs seventeen (17), though five (5) had already been used during the pilot study, thus unavailable for inclusion. Since the remaining twelve (12) firms were judged not to be many, it was found wise to include them in the study to act as a buffer zone for possible non responses. As a result, all the eighty-five (85) available MSMEs were included in the study, thus making it unnecessary to establish the sampling fraction. The collected data was analysed using descriptive statistics. 


\section{Review of Relevant Literature}

\subsection{Kenya's Manufacturing Industry}

More than eighty per cent $(80 \%)$ of the manufacturing enterprises in Kenya are based within Nairobi City County which is the capital city and political seat of policy makers in the country. The rest of the value addition outfits are mainly located in other major counties, such as Mombasa, Kisumu, Kakamega Nakuru, Uasin Ngishu, Machakos, Nyeri and Kiambu (KAM, 2018). According to RoK (2016), the manufacturing sector in Kenya recorded a decelerated growth of 3.5 per cent from a revised growth of 3.6 per cent in 2015. The sector's growth remained stifled in 2016 mainly due to underperformance of other sectors such as agriculture and energy (electricity) that provide inputs for manufacturing activities. The near stagnation in the growth of manufacturing was also manifest in the slow uptake of credit from Kshs 290.1 billion in 2015 to Kshs 276.7 billion in 2016. In year 2017, the manufacturing sector posted a marginal growth of 0.2 per cent compared to a revised growth of 2.7 per cent in 2016. The slowed growth was partly attributable to uncertainties related to the 2017 general elections, high cost of inputs and stiff competition from cheap imports. Generally, most activities in the sector recorded significant decline leading to the slowdown experienced in 2017. The volume of food products manufactured declined by 10.8 per cent in 2017 compared to 1.9 per cent growth in 2016 (RoK, 2019).

Kenya's manufacturing sector is subdivided into twelve sub-sectors which are in processing and value addition (KAM, 2018). The first one is Timber, Wood and Furniture Sector, which produces furniture and fixtures, lumber, sash, doors, windows and door frames, prefabricated wooded parts and structures, veneer, plywood, hard board and particle board, cooperage and other wood stock and excelsior. Food and Beverage is another sub sector that manufactures Vegetable Oils, Daily Products, Alcoholic Beverages and Spirits, Juices / Waters /Carbonated Soft Drinks, Bakers and Millers, Cocoa / Chocolate and Sugar Confectionery. There is also the Leather and Footwear Sector which manufactures leather and products of leather, leggings, gaiters, footwear, fabrics, and other materials. Another sub sector is the Motor Vehicle which produces engines, brakes, clutches, axle, gears, transmissions, wheels and frames, assembly, rebuilding and major alteration of complete motor vehicles such as passenger automobiles, commercial cars and buses, lorries and truck trailers. Plastics and Rubber is another sub sector that manufactures tyres and tubes, re-treading tyres, fabricating of plastic articles such as plastic dinnerware, kitchen ware, plastic mats, synthetic sausage casings, plastic containers and cups, laminated sheets, plastic components for insulation, plastic furniture, and plastic industrial supplies.

The manufacturers of tobacco products such as cigarettes, cigars, smoking chewing and homogenised tobacco and snuff, is another sub sector within the manufacturing industry. Others include: Chemical and Allied Sector - Manufacturers of basic industrial chemicals including fertilizers, pesticides, cosmetics, paints and resins; Paper and Board Sector - Manufacturers of pulp, paper and paperboard articles such as glazed, gummed and laminated paperboards, pulp plates and utensils, bottle caps, unprinted cards, envelopes and stationery, wall paper, towels, toilet paper, straws, mounts, publishing, and allied industries; Electrical and Electronics Sector - Manufacturers of electrical machinery, apparatus, appliances and supplies. Other sub sectors in the manufacturing industry include the following: Textiles and Apparel Sector - Manufacturers of wearing apparel, weaving and finishing textiles, knitting mills, carpets and rugs; Pharmaceutical and Medical Equipment Sector - Manufacturers of medical equipment, drugs and medicines; Metal and Allied Sector Smelting and Hot Rolling, pipes and tubes, wire and wire products, general fabricators and allied industries (KAM, 2018).

\subsection{Quality Management}

Quality is not a modern concept because customers have continued to demand quality goods since the advent of markets (Corwin \& Puckett, 2009). Quality can be defined by the conformity of a product to a set of legislated specifications, by the ability to meet or exceed the customer requirements, hence fitness for use (Nham \& Takahashi, 2009; Prajogo \& Sohal, 2006). The concept of quality does not only apply to the degree to which a product meets a set of predetermined standards, but is also related to its value in the market place and its fitness for purpose for which it was designed (Hu, Zheng, \& Wang, 2011; Nofal, Omaim, \& Zairi, 2005). In addition, ensuring that wastages on materials, money and other resources are minimized in the whole management and production process is also at the core of Quality Management. This approach is essential in improving product quality, efficiency and effectiveness, creating a motivated workforce and consequently gaining an edge over competitors (Chong \& Rundus, 2004; Nham \& Takahashi, 2009).

Quality management therefore advocates for the improvement of product quality and the production process as practiced within the enterprise for purposes of consumer and employee satisfaction (Bos-Brouwers, 2010). To achieve its objectives, quality management focuses more on problem solving in addition to the traditional approach of monitoring and inspecting. Quality management therefore fronts the improvement of the whole production process through elimination or reduction of defects and low value tasks. It encourages the transformation in management thinking and style to enhance quality and increase organizational productivity (Bigliardi, Colacino, \& Dormio, 2011). Higher productivity does not result from lowered 
specifications for products manufactured or services rendered (Corwin \& Puckett, 2009). Productivity starts with effectiveness (quality of products) and ends with efficiency (use of resources).

Quality management has been recognized as critical in achieving competitive advantage because it has been shown to increase productivity and overall organizational performance (Nham \& Takahashi, 2009). Studies undertaken to assess the influence of Quality Management on the performance of a selected firms. The influence of Quality management was measured by comparing each companies to that of a control group designed to capture what the firm's performance would have been had it not adopted quality management practices. The findings showed that performance, measured by excess profit margin, return on assets, asset use efficiency and stock returns, is improved for the enterprises that adopted quality management (Ahire, Landeros, \& Golhar, 1995).

Quality management encourages working smarter rather than harder, upgrading of the whole production process, deciding how many actions at what level, what functions are required, but at the same time improving the quality of work life for the employees. Its implementation process touches on many activities that are carried out in different sections in the enterprise. The objective is to strive for continuous improvement in a process through analysis and measurement, implementation of new ideas and procedures for improvement. The cycle of improvement is ongoing, and the purpose is to add value for which the customer is prepared to pay (Bigliardi et al., 2011). In an effort to improve the quality of a process, the needs of both the external and internal customers are identified. The objective is to change the mindset of the employee from one of only monitoring the process, to one of also continually looking for improvements (Jara \& Escaith, 2012). This is attained by continuously seeking the input of employees. To the external customers, the objective is to ensure that the final product satisfies the desired needs. Ultimately, the fundamental rethinking of business processes to incorporate efficiency and effectiveness as advocated by the quality management approach, results in dramatic improvements in performance measures such as cost, quality, service and speed. All these attributes are critical for enterprise competitiveness in the current internationalized business regime (Jara \& Escaith, 2012; Prajogo \& Sohal, 2006). Such an environment has resulted in a production system that is flexible, network-based, lean and competitive to serve a very dynamic market characterized by a customer whose preferences are globalized and inconstant (Jara \& Escaith, 2012; Lunati, 2007; Prajogo \& Sohal, 2006). In response to such a market environment, the need for the improvement of quality, productivity and enterprise competitiveness is recognized world over. To remain relevant in the current scenario, productivity in an enterprise must focus not only on doing the right things, but also by doing things right through constantly reviewing and improving design, manufacture and delivery systems to keep on satisfying changing customer and social needs, and also by developing products at the right quality (Bos-Brouwers, 2010; Callahan et al., 2013).

\section{Results and Implications}

4.1. Response Rate

A total of eighty-five (85) MSMEs from a different range of production units were included in the study. The study recorded $66.66 \%$ response rate which means that fifty-six (56) Chief Executive Officers, General Managers or Senior Management staff participated in the study. The non-response was due to a combination of factors including time constraint on the part of the interviewees, unwillingness and/or inability to respond to items on the questionnaire. The response rate from the various clusters as presented in Table 1.

Table-1. Response rate.

\begin{tabular}{l|c|c|c|c}
\hline \multirow{2}{*}{ Stratum } & \multicolumn{3}{c|}{ Employment levels } & \multirow{2}{*}{ Totals } \\
\cline { 2 - 4 } & $\mathbf{5 1 - 1 0 0}$ & $\mathbf{1 0 1 - \mathbf { 1 5 0 }}$ & $\mathbf{1 5 1 - \mathbf { 2 0 0 }}$ & \\
\hline Food processing & 4 & 5 & 4 & 13 \\
\hline Wood workings & 5 & 2 & 2 & 9 \\
\hline Fabricated metal products & 3 & 5 & 4 & 12 \\
\hline Non-metallic products & 2 & 3 & 4 & 9 \\
\hline Leather, Textiles \& Garments & 5 & 4 & 4 & 13 \\
\hline Totals & 19 & 19 & 18 & \multirow{2}{*}{56} \\
\hline$\%$ & 33.9 & 33.9 & 32.1 & \\
\hline
\end{tabular}

The sizes of the firms were determined based on the number of employees in the respective enterprises. As presented in Table 1. The distribution of the number of employees in the firms showed that most of the Food Processing firms had $101-150$ employees at 38.46\%; Wood Working firms at 55.55\% had 51-100 employees, while most in the Fabricated Metal cluster were at 41.66\% (101-150). In the Non Metallic Products cluster, most firms at $44.44 \%$ had $151-200$ employees as compared to the Leather, Textiles and Garments cluster where most of the firms had $51-100$ employees. There was however no significant difference in the sampled firm sizes $\left(\chi^{2}=1.721, \mathrm{P}=0.988\right)$ since the responses were well distributed across the clusters in the target group. 


\subsection{Responses on Quality Imperatives}

The mean responses on items on quality imperatives are presented in Table 2.

Table-2. Mean responses on quality imperative items.

\begin{tabular}{|c|c|c|c|c|c|c|}
\hline Opinion on item & $\begin{array}{c}\text { SD } \\
\%\end{array}$ & $\begin{array}{l}\text { D } \\
\%\end{array}$ & $\begin{array}{c}\text { NS } \\
\%\end{array}$ & $\begin{array}{l}\mathrm{A} \\
\%\end{array}$ & $\begin{array}{c}\text { SA } \\
\%\end{array}$ & $\begin{array}{c}\text { Mean } \\
\text { response }\end{array}$ \\
\hline Customer satisfaction is a major goal in the enterprise & - & 4.5 & 15.2 & 60.6 & 19.7 & 4.0 \\
\hline $\begin{array}{l}\text { Customers are involved in the quality improvement } \\
\text { process }\end{array}$ & 6.1 & 30.3 & 40.9 & 22.7 & - & 2.8 \\
\hline $\begin{array}{l}\text { The enterprise has established measures of customer } \\
\text { satisfaction }\end{array}$ & - & 3.0 & 25.8 & 60.6 & 10.6 & 3.8 \\
\hline $\begin{array}{l}\text { Employees are rewarded or penalized on the basis of } \\
\text { established criteria for meeting customer satisfaction }\end{array}$ & 10.6 & 34.8 & 28.8 & 16.7 & 9.1 & 2.8 \\
\hline $\begin{array}{l}\text { The expectations of internal customers are taken into } \\
\text { account }\end{array}$ & 12.1 & 40.9 & 33.3 & 13.6 & - & 2.5 \\
\hline $\begin{array}{l}\text { Top management are committed to the process of } \\
\text { quality improvement }\end{array}$ & - & 1.5 & 19.7 & 51.5 & 27.3 & 4.0 \\
\hline $\begin{array}{l}\text { Mid-level management are committed to the process } \\
\text { of quality improvement }\end{array}$ & 4.5 & 33.3 & 50.0 & 12.1 & - & 2.7 \\
\hline $\begin{array}{l}\text { Non-management workers are committed to the } \\
\text { process of quality improvement }\end{array}$ & 3.0 & 31.8 & 27.3 & 30.3 & 7.6 & 3.1 \\
\hline The enterprise monitors the cost of poor quality & 15.2 & 37.9 & 30.3 & 12.1 & 4.5 & 2.5 \\
\hline $\begin{array}{l}\text { The level of training within the enterprise is sufficient } \\
\text { to support the implementation of a quality } \\
\text { improvement process }\end{array}$ & 21.2 & 59.1 & 16.7 & 3.0 & - & 2.0 \\
\hline $\begin{array}{l}\text { The enterprise works with its vendors to help them } \\
\text { improve the quality of their support to the business } \\
\text { unit }\end{array}$ & - & - & 6.1 & 53.0 & 40.9 & 4.3 \\
\hline $\begin{array}{l}\text { Quality is monitored frequently throughout the entire } \\
\text { organization }\end{array}$ & 3.0 & 7.6 & 31.8 & 45.5 & 12.1 & 3.6 \\
\hline $\begin{array}{l}\text { Non-management workers are involved in setting } \\
\text { quality standards }\end{array}$ & 33.3 & 53.0 & 12.1 & 1.5 & - & 1.8 \\
\hline $\begin{array}{l}\text { Non-management workers are involved in monitoring } \\
\text { the quality of their work }\end{array}$ & 3.0 & 3.0 & 10.6 & 54.5 & 28.8 & 4.0 \\
\hline $\begin{array}{l}\text { Non-management workers are involved in monitoring } \\
\text { the quality of what they receive }\end{array}$ & - & 1.5 & 12.1 & 56.1 & 30.3 & 4.2 \\
\hline $\begin{array}{l}\text { Non-management workers are given the authority to } \\
\text { track down the source of a quality problem and to take } \\
\text { corrective action }\end{array}$ & 1.5 & 16.7 & 24.2 & 50.0 & 7.6 & 3.6 \\
\hline $\begin{array}{l}\text { The enterprise has as one of its objectives "Do the } \\
\text { right things right the first time }\end{array}$ & 4.5 & 7.6 & 24.2 & 39.4 & 24.2 & 3.7 \\
\hline $\begin{array}{l}\text { The enterprise attempts to design quality into the } \\
\text { product/service }\end{array}$ & - & - & 12.1 & 57.6 & 30.3 & 4.2 \\
\hline
\end{tabular}

As expounded in Table 2 majority of the respondents at $93.9 \%$ indicated that the firm works with its vendors to help them improve the quality of their support to the business (mean response 4.3). Nonmanagement workers are involved in monitoring the quality of what they receive (mean 4.2 ) and the business unit attempts to design quality into the product/service (mean response 4.2 ) In $80.3 \%$ of the firms, Customer satisfaction is a major goal in the business unit (mean 4.0) and the business unit has established measures of customer satisfaction (mean response 3.8 ). In $78.8 \%$ of the firms, top management are committed to the process of quality improvement while in $83.3 \%$ the Non-management workers are involved in monitoring the quality of their work (mean response 4.0). The business unit has as one of its objectives "Do the right things right the first time" in $63.6 \%$ of the firms and Quality is monitored frequently throughout the entire organization (mean response 3.6). However, Non-management workers are not involved in setting quality standards (mean response 1.8) and the expectations of internal customers are not taken into account (mean response 2.5). The business unit do not monitor the cost of poor quality (mean response 2.5).

To establish the level of performance of MSMEs in relation to the eighteen (18) tested items, a One-Way Analysis of Variance (ANOVA) was conducted on the mean response on the items tested. The mean response for the eighteen (18) items is as shown in Table 3. 
Table-3. Mean response rate.

\begin{tabular}{c|c|c|c}
\hline Factor / Item & Number of tested items & Mean response rate & Standard deviation \\
\hline Quality imperatives & 18 & 3.31 & 0.80 \\
\hline
\end{tabular}

4.3. Implications of the Study Findings

The study's findings show that MSMEs are not performing as would be expected on quality imperatives in a globalised and hyper competitive business environment where customers are spoilt for choice. These findings are in agreement with others conducted in the East African region, Africa and internationally (Mwangi \& Ngugi, 2014; Nderitu \& Ngugi, 2014; Okeke \& Eme, 2014; Tuan \& Yoshi, 2010). These findings show that some medium scale manufacturing enterprises in Kenya tend to overlook some necessary and critical quality imperatives, yet customers have over the years continued to demand quality goods and services that meet or exceed client's expectations. Poor quality impacts negatively on employees and other stakeholders because it results in reduced job opportunities, reduced bottom line and low contribution to the gross domestic product for the national economy. The findings also imply difficulties for MSMEs' in their attempt to reposition themselves for competitiveness in the local and international market. The findings are also an impediment to the realization of one of the pillars of Kenya's big four agenda and vision 2030. The findings also mean that there is work to be done by MSMEs towards the achievement of the target global sustainability agenda (United Nations Sustainable Development Summit, 2015).

Quality management is therefore a critical component in achieving competitive advantage due to its ability to enhance productivity and overall organizational performance. Therefore, an enterprise that is unable to configure its processes to achieve and maintain the desired level of excellence in product quality would become dysfunctional and obsolete in a globalized market place. To remain relevant in the current scenario, MSMEs in Kenya must focus not only on doing the right things, but also by doing things right through constantly reviewing and improving design, manufacture and delivery systems to keep on satisfying changing customer and social needs, and also by developing products that are fit for purpose. This would at the same time improve the quality of work life for the employees.

\section{Conclusion and Recommendations}

Quality is consistently meeting customer needs, wants and expectations. Quality is always a moving target because customer's needs, wants and expectations change over time. Therefore, the quality journey pursued by MSMEs should never stop. Attainment and maintenance of quality is the principle means of survival for the long term in a highly competitive and global business environment. All the processes within the MSMEs must be reengineered to undertake the quality improvement journey, because their traditional management methods seem to be wholly inadequate to attain and sustain high quality. For the purposes of continuous organization wide improvements, quality management practices including relevant training and ISO certification as appropriate should be undertaken in MSMEs to achieve improvements over the old form of the enterprise. The chosen practices should be implemented at all levels in the MSME. This can be achieved if the entrepreneur puts in place an organization wide system for quality assurance, quality control and quality improvement. This system should be communicated to staff in the entire MSME with regard to the set expectations on quality parameters, including doing things right the first time along the value chain.

\section{References}

Abeh, O. (2017). The problems and prospects of small and medium scale enterprises (SMEs) growth and development in Nigeria: A study of Selected SMEs in Delta State. International Journal of Scientific Research in Education, 1O(3), 278-294.

Ahire, S. L., Landeros, R., \& Golhar, D. Y. (1995). Total quality management: A literature review and an agenda for future research. Production and Operations Management, 4(3), 277-306. Available at: https://doi.org/10.1111/j.19375956.1995.tboo057.x.

Ayyagari, M., Beck, T., \& Demirguc-Kunt, A. (2007). Small and medium enterprises across the globe. Washington, D.C: Small Business Economics.

Banjoko, S. A., Iwuji, I. I., \& Bagshaw, K. (2012). The performance of Nigerian manufacturing sector; A 52-year analysis of growth and retrogression (1960 - 2012). Journal of Asian Business and Strategy, 2(8), 177-191.

Bausch, A. (2011). Is innovation always beneficial? A meta-analysis of the relationship between innovation and performance in SMEs. Journal of Business Venturing, 26(4), 441-457.

Bigliardi, B., Colacino, P., \& Dormio, A. I. (2011). Management \& Innovation: Innovative characteristics of small and medium enterprises. Amsterdam: Butterworth-Heinemann.

Bos-Brouwers, H. E. J. (2010). Corporate sustainability and innovation in SMEs: Evidence of themes and activities in practice. Business Strategy and the Environment, 17, 417-435.

Callahan, C. M., Smith, R. E., \& Spencer, A. W. (2013). The long-term performance consequences of strategic partnerships in high tech industries. Journal of Applied Business Research (JABR), 29(1), 217-234. Available at: https://doi.org/10.19030/jabr.v29i1.7569.

Chong, V. K., \& Rundus, M. J. (2004). Total quality management, market competition and organizational performance. The British Accounting Review, 36(2), 155-172. Available at: https://doi.org/10.1016/j.bar.2003.10.006. 
Corwin, J., \& Puckett, R. (2009). Japan's manufacturing competitiveness strategy: Challenges for Japan, Opportunities for the United States. Tokyo: Department of Commerce, International Trade Administration.

Daveri, F., \& Lasinio, C. J. (2007). Offshoring and productivity growth in the Italian manufacturing industries (Vol. 22). Italy: WP 08/2007, University of Parma.

Haltiwanger, J., Jarmin, R., \& Miranda, J. (2010). Who creates jobs? Small vs. large vs. young. Cambridge, London: National Bureau of Economic Research.

Hu, Z., Zheng, J., \& Wang, J. (2011). Impact of industrial linkages on firm performance in Chinese development zones, Yangtze River Delta, Jiangsu Province, China. The Chinese Economy, 44(2), 78-105.

Jara, J., \& Escaith, H. (2012). Global value chains, International trade statistics and policymaking in a flattening world. World Economics, 13(4), 19-38.

Kenya Association of Manufacturers. (2018). Survey of the manufacturing sector in Kenya. Nairobi: Kenya Association of Manufacturers.

Khrystyna, K., Mirmulstein, M., \& Ramalho, R. (2010). Micro, small, and medium enterprises around the world: How many are there, and what affects the count? Washington, D.C: IFC and World Bank.

Klapper, L., Amit, R., \& Guillen, M. (2008). Entrepreneurship and firm formation across countries. Washington, D.C: World Bank.

Krejcie, R. V., \& Morgan, D. W. (1970). Determining sample size for research activities. Educational and Psychological Measurement, 30(3), 607-610. Available at: https://doi.org/10.1177/001316447003000308.

Leahy, D., \& Montagna, C. (2008). Make or buy in international oligopoly and the role of competitive pressure. GEP Research Paper, University of Nottingham, 63.

Liesch, P. W., Buckley, P. J., Simonin, B. L., \& Knight, G. (2012). Organizing the modern firm in the worldwide market for market transactions. Management International Reviere, 52(64), 3-21.

Lunati, M. (2007). The OECD Tokyo Action Statement for Strengthening the Role of SMEs in Global Value Chains adopted at the OECD Global Conference in Tokyo, on 1 June 2007. Retrieved from: https://www.oecd.org/japan/38774814.pdf.

McGrath, R. G. (2013). Transient advantage. Harvard Business Review, 91(6), 62-70.

McKenzie, D. (2011). How can we learn whether firm policies are working in Africa? Challenges (and Solutions?) for experiments and structural models. Washington, D.C: World Bank.

Mead, D., \& Liedholm, C. (1998). The dynamics of micro and small enterprises in developing countries. East Lansing, Mich: Michigan State University.

Mwangi, M. M. A., \& Ngugi, K. (2014). Influence of entrepreneurial orientation on growth of Micro and small enterprises In Kerugoya, Kenya. European Journal of Business Management, 1(11), 417-438.

Nderitu, K., \& Ngugi, K. (2014). Effects of green procurement practices on an organization performance in manufacturing industry: Case study of East African Breweries Limited. European Journal of Business Management, 2(1), 341-352.

Nham, P., \& Takahashi, Y. (2009). Resources, organizational capabilities and performance: Some empirical evidence from Vietnam's supporting industries. International Review of Business Research Papers, 5(4), 219-231.

Nofal, A. A., Omaim, A. N., \& Zairi, M. (2005). Critical factors of TQM: An update on the literature. Bradford University School of Management, Working Paper No 05/23.

Okeke, M. I., \& Eme, O. (2014). Challenges facing entrepreneurs in Nigeria. Singaporean Journal of Business: Economics and Management Studies, 3(5), 18-34.

Organisation for Economic Co-operation and Development. (2004). Promoting entrepreneurship and innovative SMEs in a global economy. Paris, France: OECD.

Oslo Manual. (2005). Guidelines for collecting and interpreting innovation data. Organization for Economic Co-Operation and Development (OECD) 2000, 166

Prajogo, D. I., \& Sohal, A. S. (2006). The integration of TQM and technology/R\&D management in determining quality and innovation performance. Omega, 34(3), 296-312. Available at: https://doi.org/10.1016/j.omega.2004.11.004.

Republic of Kenya. (2012). Kenya vision 2030: Ministry of state for planning, national development and vision 2030. Sessional Paper No. 10 of 2012. Nairobi: Government Printer.

Republic of Kenya. (2016). Economic survey 2015: Kenya national Bureau of statistics. Nairobi, Kenya: Government Printer

Republic of Kenya. (2019). Economic survey of 2018. Kenya National Bureau of Statistics: Ministry of planning and national development. Nairobi: Government Printer.

Rice, T., \& Strahan, P. E. (2010). Does credit competition affect small-firm finance? The Journal of Finance, 65(3), 861-889. Available at: https://doi.org/10.1111/j.1540-6261.2010.01555.x.

RoK. (2013). Economic survey 2012, Kenya national Bureau of statistics. Nairobi: Government Printers.

Saldaña, J. (2011). Understanding qualitative research: Fundamentals of qualitative research. Oxford University Press.

Sinha, P., Akoorie, M. E., Ding, Q., \& Wu, Q. (2011). What motivates manufacturing SMEs to outsource offshore in China? Comparing the perspectives of SME manufacturers and their suppliers. Strategic Outsourcing: An International Journal, 4(1), 67-88. Available at: https://doi.org/10.1108/17538291111108435.

Tuan, N., \& Yoshi, T. (2010). Vertical linkage and firm's performance in supporting industries in Vietnam. Asian Journal of Management Research, 1(1), 1-14.

United Nations Sustainable Development Summit. (2015). Transforming our world: The 2030 agenda for sustainable development. New York: United States of America. 